\title{
GLOBALISATION AT THE CROSSROADS? THE REVIVAL OF NATIONALISM AND IDENTITY POLITICS
}

\author{
ANTHONY MILNER \\ Asia Europe Institute, University of Malaya \\ anthony.milner@um.edu.my \\ Dihantar: 27 Feb 2020 / Diterima: 29 April 2020
}

\begin{abstract}
This article is a revised and expanded version of the author's keynote address for the inaugural International Conference on Politics and International Studies (ICPIS) 2018, held in Kota Kinabalu, Sabah, Malaysia. The title reflects the official theme of the said scholarly congregation, which deliberates on the contested notions of globalisation and the phenomenon's related outcomes, including its much touted hegemonic, universal liberal qualities, which have elicited a backlash that has seen the revival of nationalism and identity politics during the last few decades. That globalisation has arrived at a crossroads and the thought of what might lie ahead is what this paper seeks to ponder, through the prism and critique of both recent as well as older works by the likes of Francis Fukuyama, Charles Taylor, Wang Gungwu and Samuel P. Huntington. More specifically, it critically explores the evolution and progress of globalisation from both historical and international relations (IR) perspectives, explicating watershed eras in the long cycle of modern international history that had as much facilitated as hindered the realisation of a universal liberal consensus, or liberal triumph. Although concluding that globalisation has been stopped in its tracks, the article nevertheless, expresses concerns regarding the limitations of Western-oriented IR as a discipline in comprehensively grasping the complexities of post-globalisation dynamics shaped by culturalideational specificities, not to mention, the fallacy of overemphasising on "identity politics" as a "master concept" in explaining all that is happening in contemporary world politics. Instead, it contends on the need to review existing analytical frameworks, while exploring new "logics" in the quest to construct new paradigms to help make sense of a post-globalisation, post-liberal, probably post-Western era.
\end{abstract}


Keywords: Globalisation, identity politics, culture, liberal, international relations.

\section{INTRODUCTION}

We often hear that globalisation has arrived at a crossroads but how seriously do we think of the implications about what might lie ahead of the crossroads? In this article, I will focus on some recent writing by Francis Fukuyama and some older writing from Charles Taylor, Wang Gungwu and Samuel Huntington.

First, however, that distinguished theoretician Donald Trump explained in September 2018 that "we reject the ideology of globalism," and "embrace the doctrine of patriotism." Such a vision of what lies ahead seems overly simplistic, overly restrictive. Globalisation/patriotism, the global/the state - are there no other options?

In his new book, Identity: Contemporary Identity Politics and the Struggle for Recognition (2018), Francis Fukuyama suggests one further option. He argues that halfway through the first decade of this century the advance to a liberal world order "began to falter" (5) and politics began to be "defined by identity," with an emphasis on promoting the interests of such groups as "blacks, immigrants, women, Hispanics, the LGBT community, refugees, and the like" (6). This "politics of resentment" (7) is concerned with the dignity of particular groups - with gaining "recognition" for these groups (10). Fukuyama said, Human beings "crave positive judgments about their worth or dignity" (18).

In Identity, Fukuyama suggests how this concern for recognition, this politics of identity, came about. He examines Greek thought and the development of individualism (of a sense of the inner self) which took place in the West - and does so drawing on the work of the philosopher Charles Taylor. However, when Fukuyama argues that identity politics has not only pushed aside politics "defined by economic issues" (6) but also has become a "master concept that unifies much of what is going on in world politics today" (xv), his argument becomes too ambitious. There seems to me to 
be more going on in the world today than identity politics. Also, some of what is going on is more radical than identity politics, and less grounded in Western tradition. Taylor, it seems to me, is better prepared than Fukuyama to understand this.

\section{The new era - structural changes}

Fukuyama is right to recognise that we are in an era of profound change and it is not surprising that social analysts are scrambling to find paradigms that capture the direction in which we are heading. Just thinking of the Asian region, the idea of globalisation has certainly been potent. The region has been structured in a range of ways over recent centuries. Before the $19^{\text {th }}$ century consolidation of Western colonialism, hierarchy was fundamental. Within the individual political units or polities, hierarchical arrangements flowed outwards from the ruler - defining and organising different levels among the ruler's subjects - and the relationship between polities was hierarchical as well, with China at the pinnacle of the regional order. Hierarchy, it is clear, presented opportunities as well as threats for all concerned - and was not necessarily resisted.

In the $16^{\text {th }}$ and $17^{\text {th }}$ century the idea of the territorial state - the polity defined by its physical boundaries rather than personal ties with a ruler - began to be influential, partly as a result of European influence, and then in the $19^{\text {th }}$ and $20^{\text {th }}$ centuries the whole region came under Western imperial rule or influence. The great centres of power were then London, Paris, Washington and The Hague - and the Asian region was divided into different colonial states or spheres of influence. There were other competing constructs or ways of configuring the region, of course, and one highlighted the concept of 'Asia' - of a vision (developed largely in India and Japan) of the entire region as a specifically 'Asian' collaborative community. The Western imperial structure, however, remained dominant - at least until the sweeping Japanese victories of 1941/1942.

After the Pacific War, the region saw the emergence of nation states based largely on the colonial states with respect to territorial definition and even governmental organisation. The rapid development of the Cold War - with its 
great struggle between Communists and anti-Communists - then impinged on the region, structuring relations between the component countries, some on one side, some on the other, with a number of countries attempting to keep out of the struggle, seeking some form of neutrality or equidistance.

With the end of this Cold War, the last decade of the $20^{\text {th }}$ century experienced what some have termed a unipolar moment. United States hegemony seemed unchallengeable, and economic globalisation - with a reduction in transaction costs and an increase in the flow of goods, services, information, capital and people appeared to be increasingly accompanied by a growing global consensus on values. There was talk of a 'global spread of liberal democracy', an 'emerging global civilisation' and a 'single world society'. Fukuyama, writing at that time in a way that brought him international renown, announced the 'end of history'. There would no longer, he suggested, be an alternative to liberalism - such liberal institutions as free markets and representative government were becoming universal. In Asia, Governor Patten in Hong Kong believed nothing could halt the spread of liberal values; and Foreign Minister Gareth Evans of Australia included the spread of the English language to this global liberal agenda.

There were signs of movement in the opposite direction, it is true. The 1989 suppression of protest in Tiananmen Square was one example; the advocacy of 'Asian values' in Southeast Asia particularly in Malaysia and Singapore was another. The economic success of a number of Asian societies, it was argued, was a result in part of the influence of specifically Asian values rather than the adoption of Western economics. Government social policy in many areas was also praised for responding not so much to Western prescriptions but to long-held Asian values such as the stress on community rather than the individual, and on economic rights more than political rights. In Malaysia in the early 1990s Prime Minister Mahathir pressed for an 'East Asian' regional grouping in contrast to the growing trend toward a United States-led 'Asia-Pacific' regionalism. The Europeans, he pointed out, were developing 'European' regionalism, why should there not be an emphasis on 'Asian' regionalism, bringing together the ASEAN counties with Japan, China and South Korea? In this sense, Mahathir was prioritising 'Asian' identity rather than 'global' processes. 
Mahathir's ambitions were frustrated, however - pushed aside by the APEC (Asia Pacific Economic Cooperation) project, a regional grouping formed not on an 'Asian' but rather an 'Asia-Pacific' foundation (and underpinned by a powerful United States). The tables turned later. During the Asian Economic Crisis of 1997-1998, APEC and the IMF (International Monetary Fund) were seen by many to be relatively unhelpful and Western prestige was damaged when China took measures that served to benefit the region (especially holding its currency solid against the US dollar). With the rise of ASEAN Plus Three (APT) cooperation between the ASEAN states, China, Japan and South Korea in the last years of the century, something close to Mahathir's 'East Asia' vision came into being. But I am moving too fast.

\section{Globalisation triumphant}

In the early 1990's, when it looked as if a United States-led order, founded on a convergence of norms and values on a liberal basis, would be the successor to the Cold War, one could see evidence of liberal triumph in the fate of a powerful book. In his The Clash of Civilizations (which elaborated the argument of an article published in 1993), Samuel Huntington, like Mahathir, spoke against the prediction of liberal triumph - but primarily on analytic grounds. He argued that far from achieving a liberal consensus, the world - at the end of the Cold War - would see "great divisions among humankind" and that the essential "conflict would be cultural". Huntington pointed, for instance, to the "Islamic resurgence" movement, and said it involved the "rejection of Western culture and a recommitment to Islam as the guide to life in this world". He also saw China as a "civilisation" rather than a "state". It was above all, he said, the contest between Western, Islamic and Chinese civilisations that would constitute the 'clash of civilisations'.

Huntington's 'Clash' paradigm certainly made an impact, being condemned from one direction after another, particularly by believers in an ascendant liberal order. Australia's Gareth Evans pointed out that Huntington had not explained why countries with common Confucian roots can clash for example, North and South Korea or why loyalties might shift from nation state civilisation (Evans, 1993). Huntington, his critics said, had 
underestimated the way one so-called civilisation can often influence or be influenced by, another. 'Civilisation', they added, was no match for the 'liberal order'. Even in the case of China, John Ikenberry (2011) argued that it would not wish to create a non-Western world order but would eventually integrate into a version of the "liberal world order".

It is worth pausing here to consider some of the consequences which flowed from assuming the dominance of the liberal order. One was in the way social and political developments have been analysed. At the unipolar, globalising, liberal highpoint of the early 1990's many analysts saw no point in exploring other perspectives - specifically non-liberal, non-Western ways of thinking. As one commentator from the discipline of International Relations observed, students were not pressed to be curious about the nonWest. They were encouraged to explain away "non-Western" dynamics by "superimposing Western categories" (Pinar, 2007: 11). At this time, 'culture' as the anthropologist Clifford Geertz (1995) saw things - was on the defence as a factor in analysis. Questions "rained down" on the "very idea of a cultural scheme".

With respect to Huntington's work, it was not just his paradigm of a 'clash of civilisations' that came under attack. The fact that he gave weight to structures of belief and experience, to the identification and analysis of structures that differ from modern Western ones - this in itself could be held up to ridicule. In a globalised world, where we could presumably all agree on the issue of what drives human beings, there was little need to bother with culture, or perhaps history as well. People as perceived in this era of Western confidence would behave as people do, just as states are states and do what states do. The 'nation state', 'sovereignty', 'power', and the 'balance of power' were the key concepts that were believed to transcend any apparent cultural boundaries. As the International Relations practitioner, Kenneth Waltz (1996) put it, "states similarly placed behave similarly despite their internal differences".

Looking back today on the Huntington 'Clash' debate, the idea of great civilisational blocs - Chinese, Islamic, Western etc - is not very helpful. It is indeed too rigid a paradigm and it is hardly surprising that it 
was dismissed quickly in a period when globalisation was gaining such pace. Partly because of events taking place since that time, however, it does seem to have been a mistake to condemn Huntington for taking culture seriously as a factor driving human action. In retrospect, what was most important about Huntington's writing in the early 1990's was his warning of the danger of assuming the universality of Western culture. It was in fact his attempt to retrieve culture - to insist that differences in culture had to be confronted by analysts - that won him rare praise in the 1990's. Distinguished historian Wang Gungwu, for instance, complimented his frankness about the "relative decline of the West" and his observation about the "increasing inadequacy of Eurocentric models of international politics in the contemporary world". Wang (1996/1997) noted that Huntington had opened up the possibility of a "new logic and language of behaviour". What Wang focused on, therefore, was not Huntington's structure of civilisational blocs but rather the fact that, in the midst of all the 1990s talk about globalisation-about the emergence of a single world culture - Huntington was boldly insisting that cultural specificities still mattered.

Today it is increasingly clear that investigations of international state behaviour must confront stubborn cultural specificities - categories of experience or what Clifford Geertz (1973) once referred to as the "webs of significance" that influence social and political behaviour. Even in International Relations analysis we need to be open to the possibility that different 'logics' may operate.

The point here, in the context of the themes of this conference, is that globalisation- in its insistence on the emergence of a single world system - had cast cultural specificities aside. As it has turned out, however, as we have moved into the $21^{\text {st }}$ century, it has become clear that a whole range of local cultural perspectives are powerful and demand to be recognised in the way we interpret social and political developments. The presence of such perspectives, of course, makes for an untidy international landscape and that is something often associated with the end of an era. 


\section{Identity Politics - its limits}

Theorists in such times of transition often seek some unifying framework that might encapsulate a new age, and it is perhaps in this spirit that Fukuyama (2018) has suggested 'identity politics', the demand for recognition of one's identity, as a 'master concept that unifies much of what is going on in world politics today'. This search for recognition as he has noted, is significant especially in Western societies - and interesting also in the way that it cannot just be satisfied through a redistribution of wealth. Having said this, there is surely more happening in this post-globalisation period than the emergence of more and more sub-groups all demanding respect.

'Identity politics' does not capture the profound questioning of global liberalism that is underway at present and the need to understand that questioning, as I think Charles Taylor might put it. It does not address the need as Wang Gungwu suggests, to confront the possibility that different 'logics' may be operating influencing human actions in different parts of the world.

The concept of identity politics certainly takes into account that different interest groups exist in the world - groups that define themselves by race, sexual orientation and many other criteria - but it also sweeps them all together, in the sense that they are all said to be motivated by the same fundamental desire. In every case there is the same driver - the desire for recognition, grounded (in Fukuyama's opinion) in the Greek idea of thymos. This craving for positive judgements about one's worth, this desire for recognition, Fukuyama describes as "a universal aspect of human nature" (Fukuyama, 2018: 23). So, even as he admits the evidence of an obstacle to liberal globalisation, Fukuyama insists that identity politics is itself universal a global explanatory master concept.

Once again, cultural specifics are pushed aside and we are told that a Western tradition of thought reaching back to a Greek concept is also a universal tradition. In a sense, identity politics would seem to be not so much a radical rejection of globalisation as the title of this conference suggests but rather a facet of globalisation. 
Putting Fukuyama aside for the present, if we wish to identify genuine rejection of the liberal globalisation agenda we might look carefully at some Islamic or Chinese pronouncements. Or we could turn, for instance, to the 1993 Bangkok Declaration on Human Rights, which questioned the idea of universal human rights and insisted that Asian 'cultures and traditions' be taken into account. As indicated above, certain political leaders and thinktanks discussed 'Asian values' in the 1990's and were vocal in questioning Western liberalism. Although often ridiculed in Western commentary (Milner, 2000: 56 - 58, these Asian Critiques were and are serious. I think especially of Singapore's rejection of liberalism, discussed in Chua Beng Huat's (2017) recent book, Liberalism Disavowed: Communitarianism and State Capitalism in Singapore. In Malaysia, even in the Malaysian Institute of Moderation, the opposition to liberalism has been blatant. In a seminar on the topic in 2016, Khalif Muanmar warned that liberalism sidelines Shari'ah Law and threatens both Malay monarchy and Malay sovereignty. The liberalism movement, he said, is "well organised and has access to foreign funding" ('Bersatu banteras ancaman liberalisme' Unite to wipe out the threat of liberalism, Utusan Malaysia, 5 October, 2016).

Here is an explicit rejection of liberal globalisation, but what seems most important is the deeper issue of different logics of understanding different logics. Fukuyama does not give sufficient attention to this angle. As noted already, he cites Charles Taylor's (1992) work on the 'politics of recognition' but Taylor is more sensitive to cultural specifics. He insists on the "willingness to be open to comparative cultural study". In the process of giving serious recognition to others, says Taylor, we may have to tackle viewpoints that are "strange and unfamiliar to us". Taking others seriously, understanding what is important to them, may require us to revise our own cultural horizons. This, it seems to me, is what is almost certainly involved when we agree to take cultural specificities into account.

Let us examine in greater depth some examples of cultural specificities that seem influential - noting how they entail more than a yearning for recognition and respect. They are specificities which pose a sharp challenge for the type of political or social analyst who relies on a universalising methodology to interpret human behaviour in all manner of 
contexts. Looking at developments in Indonesia and elsewhere in Southeast Asia, the Islamisational process that is employing modern technology to tackle modern issues partly on the basis of long-held religious perspectives gives support to Samuel Huntington's prediction about the reassertion of "indigenous, historically rooted" mores and beliefs (Huntington, 1996). It is not just that these Islamic beliefs can help to create an identity-based community - a civilisational bloc. They can also challenge influential Western thinking in one area after another. The idea of the Islamic umma - the community of Islam can be seen to undermine the post-Westphalian concept of a 'community of states', with its separation of 'state' from 'church'. Also, in contrast to the Shari'ah which grounds rules and duties in the word of God - the notion of a community created by human beings rather than God may suggest an attempt to deify the human. True sovereignty, according to such an Islamic point of view, could not be attributed to a man-made state - it can only be based on divine authority.

According to one Islamic commentator on the discipline of International Relations, the stress on "states, power and sovereignty" in IR does not "capture the realities of the Muslim world view, nor always the behaviour of states and elites in the Islamic world" (Shahrbanou, 2010). From an international relations perspective, therefore, we might ask what impact could stronger Islamic religious demands have on Indonesia's - or perhaps Malaysia's - interaction with foreign countries.

\section{Intra-Asia relations post-globalisation}

Islamic perspectives are sometimes formulated with precision, so their significance as cultural specificities is relatively easy to define. However, stubborn local perspectives are to be encountered in many different types of non-Muslim societies. It is difficult to avoid focusing here on the contests in the South China Sea and noting the failure of many analysts to detect the different drivers or 'logics' at work in these disputes. Foreign observers met a cultural brick wall, for instance, in July 2016 when the Permanent Court of Arbitration made a ruling regarding the China-Philippines dispute - a ruling in favour of the latter and rejecting China's historic claims to an extensive region of the South China Sea defined by the so-called nine-dash line. 
Although the United States, Australia and some other governments called the Court's decision 'legally binding', the Chinese government declared the decision 'null and void' and said it possessed no 'binding force'.

The reaction of many in the ASEAN region to this confrontation has also proved puzzling for outside observers. Robert Kaplan, for example, had foreshadowed "all of these littoral states" in the South China Sea being arrayed "against China" and becoming "dependent upon the US for diplomatic and military backing" (Kaplan, 2014). In fact, the Southeast Asian response to the court ruling and China's reaction was "overwhelmingly muted" (Thayer, 2016; Milner, 2016). Far from a preference for muscular pushback, the ASEAN preference seemed to be for what might be called a 'smart accommodation' with China. The new President of the Philippines, Duterte, declared that "war is not an option", and called for "peaceful talk" (Peel, 2016).

It is in inter-state developments such as these that analysts need to investigate the possibility that different 'logics' are at work - and in this respect, recent interest in non-Western International Relations (non-Western IR) seems promising. Islamic claims or the dynamics of current ASEANChina interaction do not just raise issues about claims to recognition by subgroups, or even about the building of new identities and new loyalties based on cultural or religious or civilisational values. Non-Western IR is helpful because it is open to the possibility that interactions in the international sphere may be influenced by ideas that are 'fundamentally different' from those grounded in the post-Westphalian state and inter-state model.

This is not the same as arguing that different societies have intrinsically different characteristics. Of course, one society can and does influence another, and cultures alter or evolve from one period to the next. To take seriously foreign-relations concepts from different directions and different eras is not essentialism, but in the case of historically-embedded concepts - just the uncovering of perspectives that were once influential and might continue to be reference points (conscious or unconscious) in the development of foreign policy today. 
Thinking about such reference points with respect to China's approach to the South China Sea, I am struck by a comment from the Chinese scholar, Shen Dingli. China's claim, he has explained, is "neither a national boundary (conventionally depicted as a solid line) nor an unsettled border (usually depicted by a dotted line)" (Shen, 2014). This contrasts with the view of the analyst Bill Heyton that China is asserting "ownership of the South China Sea itself" (Milner, 2017). On another front, both a project at the Australian National University in Canberra, Languages of Security in the Asia Pacific, and discussions with specialists from China meeting at the Institute of China Studies at the University of Malaya, have made me interested in exactly what is meant by 'sovereignty' in Chinese discourse. How close is it to a Western understanding of 'sovereignty'? I do gather that the Chinese interpretation carries older connotations including a greater degree of flexibility regarding territorial definition and there are questions about the degree of authority over 'subject' communities which the term implies. Some suggest also that the Chinese interpretation places a strong emphasis on dignity or face. Such observations lead to the question, exactly what does it mean to say the South China Sea is under Chinese sovereignty?

Another issue which arises in the South China Sea and elsewhere is whether the Chinese approach - despite often using the language of modern state-to-state relations, with an implication of equal sovereignty - is shaped to some extent by older hierarchical relationship concepts. Sensibly enough, some Western scholars Barry Buzan, for instance - are seeking a closer understanding of the old tribute system that once helped to articulate regional relations. As Buzan and Zhang have put it, that system has features that are "not easily captured by a theoretical language derived from Western history and experience" (Zhang \& Buzan, 2012). The idea of 'sovereignty', they say, does not seem applicable; and even 'suzerainty' is not quite right, as it does not get at the idea of moral authority in the tribute system. A book I have found helpful in scrutinising Chinese perspectives is Yan Xuetong's (2013) Ancient Chinese Thought, Modern Chinese Power. Yan examines writings from the pre-Qin period and uncovers what he calls a "hard core" of "key assumptions" - assumptions that were once important in interstate relations and may still be of some significance today. He looks, in particular, at the idea of 'humane authority', and notes that it requires taking a lead in 
implementing international norms. That observation alone gives us pause in considering what China might be hoping to achieve in modern times.

Enough has been said here to indicate that there is plenty of need to urge non-Western IR specialists to continue investigating Chinese thinking and how it might be challenging globalisation. We seem to encounter here stubborn cultural perspectives, cultural logics, that require to be understood and it would be unwise to dismiss such perspectives as being offered merely in the process of claiming recognition in the context of an international 'identity politics'.

Turning from China to the Southeast Asian states in the South China Sea contest, again we encounter significant cultural specificities - ones that are also difficult to cope with through established Western IR analysis. The Duterte reaction to the Court ruling was a warning about how important it is to investigate the frameworks in which Southeast Asian policies are embedded. The concepts of power, state and sovereignty may often be helpful, but they can also get in the way of understanding some inter-state behaviour. In recent times I have been interested in Malaysian approaches to foreign relations, and this has included how Malaysia has been handling the South China Sea disputes. Malaysia's claims clash with those of China in this unequal tussle but the Malaysians seem remarkably relaxed in defending their position. Looking at statements from Malaysian leaders over recent years, there is continuity in the Malaysian approach. In 2014, when China sent a naval squadron to an area claimed by Malaysia, the Malaysian Defence Minister spoke of the need for "self-restraint" in "resolving disputes by peaceful means". The Foreign Minister insisted Malaysia was "not confrontational and wanted to engage China (Milner, 2017: 232 - 233). Prime Minister Mahathir, in an interview in 2018, said he opposed naval ships being in the South China Sea, and presumably included United States and other Western ships. He said naval ships could "create tension" and explained that he only wanted "small boats" to patrol the region, looking out for pirates. Mahathir also pointed out that Malaysia had turned some rocks into small islands four or five of them, he said - and he hoped Malaysia could stay on those islands. As for the rest of the South China Sea, he observed, "whoever thinks it is theirs can occupy" ("Mahathir clarifies his position on China, 2018). 


\section{Malaysia case-study}

The Malaysian response in these cases seems almost nonchalant - even though we know Malaysia continues to have various forms of military cooperation on a number of fronts, including with the United States and Australia. What I think we do not see in the Malaysian behaviour is an active balancing of power against China, or even a serious hedging. True, Malaysia seems happy enough to have a mix of countries in the region, and not just a powerful China - but that is not the same thing as aligning in one way or another against China (Sultan Nazrin Shah's Keynote Address at the ASEAN-Australia Dialogue, 2018). Also, Mahathir and his predecessor prime ministers have all conveyed that in general they are able to live with hierarchy. Malaysia, they often say, is merely a 'small country' (Ono, 2018), and they say this without any apparent embarrassment. China, of course, is acknowledged to be a nation of superior status and Malaysian leaders sometimes refer to the centuries of experience - going back to $14^{\text {th }}$ century Melaka and beyond - which Malaysia has had in dealing with the Middle Power (Zuraidah Ibrahim \& Jaiparas, 2018).

Malaysian political leaders look back in time - but analysts of Malaysian foreign policy seldom do so. It tends to be assumed that foreign relations experience could only go back to 1957, at the time of the creation of the modern Malayan state. This lack of historical context is curious. The first prime minister of the country, Tunku Abdul Rahman, was a prince from Kedah, a sultanate that had long experience of diplomatic juggling - hierarchical juggling between Thailand, Burma and different European powers. Also, the old Malay writings in particular the Hikayat Hang Tuah often focus on foreign relations matters. They are at least as valuable, in my view, as the pre-Qin writings in which Yan Xue Tong has identified hard-core Chinese perspectives with a relevance today.

In assessing Malaysia-China relations, of course, a wide range of factors need to be taken into account. The economic advantages which Malaysia enjoys in its China relationship, the large Chinese minority grouping in the Malaysian population, and as Kuik (2013) has pointed out the quest for 'performance legitimacy' on the part of the Malaysian regime. 
There are also ideational factors, and these include hard-core perspectives - cultural specificities - from the pre-modern Malay heritage, which help to explain some of the peculiarities of modern Malaysia's approach to foreign relations.

Thinking about Malaysian behaviour in the South China Sea, it would appear relevant that there is no obvious concern about 'sovereignty' in that heritage - no insistence on equal sovereignty between states; no sharp anxiety about the need to operate in a hierarchy; no immediate stress about the need to compromise sovereignty in certain ways. It is not surprising that Malaysian leaders today are relaxed about calling Malaysia a 'small country (Milner, 2015: 33). There is also in pre-modern texts no serious concern about territory - no stress on a ruler having authority over a specific territory; no insistence that a political unit (a state) be defined in terms of its territorial dimensions; no sharp preoccupation with geographic borders. The vital relation in the pre-colonial polity was personal - the personal relation between ruler and subject. Rulers were sensitive when it came to losing subjects and also keen to gain new subjects. When European officials asked them about borders, however, the rulers tended to give vague answers - such as, 'somewhere up that river' (Milner, 2011: Chapter 3).

How far this heritage of ideas regarding territory and borders might influence modern Malaysia's seemingly relaxed approach to territorial sovereignty is a question of obvious interest. The other question, of course, is to what extent Malaysia's extensive experience of working in a regional hierarchy - of accepting, for instance, that China or Majapahit or Siam were far greater states than Melaka, and that benefits as well as dangers might arise from this inequality - helps to shape modern Malaysia's relations with China. Not only do Malaysian leaders freely admit the greatness and regional pre-eminence of China, but they also see that a strong tie to China can help Malaysia's prestige in its immediate Southeast Asian region. Thus, Prime Minister Tun Razak claimed that his 1974 landmark visit to China made Malaysia "special in Southeast Asia" (Milner \& Siti Munirah Kasim, 2018: 385). Kuik Cheng Chwee has noted the way Malaysia "as a small state" has "capitalised on its working relationship with China" - for instance, in initiating the East Asia Summit in 2005 (Kuik, 2013: 455). 
In considering Malaysia's long tradition of handling hierarchical relations, the Hikayat Hang Tuah and other Malay texts are full of advice. They highlight shrewd behaviour, creative diplomacy - they draw attention, for instance, to the manner in which skilful letter-writing can express respect without lowering the writer's own status. They suggest too how to use one inter-ruler relationship to benefit another. Reading about this manoeuvring one is reminded often of the mousedeer, Pelanduk Jenaka, in Malay folklore - the small animal who employs all types of cunning ruse to handle and sometimes frustrate the larger animals in the jungle (Milner \& Siti Munirah Kasim, 2018: 384 - 385).

To see mousedeer behaviour today we might look more carefully at Prime Minister Mahathir's approach to China. He has called China "big and powerful" and has seemed to take a conciliatory tone on South China Sea issues. He has pointed out that "ever since the first visit to China by Malaysia's second prime minister", Malaysia has "conducted good relations with China" - and that, in fact, Malaysia's relationship with China has lasted over 2000 years. Malaysia has "looked to Beijing to help maintain peace in the region" and Mahathir has supported strongly China's Belt and Road Initiative - insisting that he only has concerns about specific projects. He speaks respectfully but also insists that certain financial deals - agreed to by his predecessor as prime minister - must be renegotiated. Mahathir's demands have been large, but the shrewd way they have been formulated would seem to be in a long tradition of Malay mousedeer diplomacy (Lokman Mansor, 2018; Jaipragas, 2018; Global Times, 20 Aug. 2018; YouTube, 19 June 2018). His manoeuvring has also had success - in particular, in a thirty per cent cut in the cost of one major project negotiated by Malaysia’s last government (Lo K, 2019).

Another seemingly relevant feature of pre-modern Malay hierarchical diplomacy as revealed in Malay writings is a stress on 'embracing' rather that 'resisting' a rising, major power. This is not to deny that such a major power might be feared but there appears to be no automatic resort to powerbalancing. The instinct - so these writings suggest is rather to engage and socialise. A powerful example of this occurs in the last pages of the Hikayat Hang Tuah, and it concerns the rising power of the Dutch (in the $18^{\text {th }}$ 
century). The Johor sultanate, so the text relates, focuses not on building an alliance against the new power from the other side of the world, but rather on building emotive relations with the Dutch (berkasehkasehan). Again, there are similarities today. Some commentators on Asian developments thought Mahathir's struggle over the business deal with China heralded the forming of some type of Asian alliance against China (Catherine Wong, 2018); in fact, however, what the Mahathir government appears to have been seeking is what I have called above, a 'smart accommodation' with China (Milner, 2017: 861). The Malaysians were not questioning China's pre-eminence - they merely sought a high-quality, mutually beneficial, hierarchical relation with that large country.

This perspective is difficult to comprehend for many analysts today, as it requires suspending assumptions about balance-of-power imperatives, as well as about equal and territorial sovereignty. A problem in the field of International Relations is the extent to which the discipline operates in a power register. True, assumptions about the primacy of power as a driver can help to throw light on specific episodes in inter-state relations, but it can also be limiting - as it may be in the study of Southeast Asia-China interaction.

As noted above, the anticipation of a coming liberal order which came with globalisation, injected extra confidence in the idea that one type of analysis fits all - that cultural specificities are merely trivial considerations. In the dominant traditions of analysing inter-state behaviour, specificities operating outside the power register have certainly been difficult to take seriously. As different as they are, both Islamic religious belief and longheld assumptions about inter-state hierarchy include drivers that operate outside the power register - drivers that we might be more likely to describe as religious or social in character.

This is not the place to go deeply into the range of factors influencing Malaysian and other Asian approaches to international relations, including the way a pre-modern heritage of ideas might provide reference points that influence policy makers, consciously or unconsciously. Nevertheless, to elaborate on the argument that 'identity politics' is inadequate as a master concept, let me at least headline two other perspectives from Malay tradition 
that might still be influential in foreign relations today. The first is the dictum against interfering in the internal arrangements of a foreign state, even a state further down the regional hierarchy. Not to interfere in the customs (the adat) of another kingdom is advice mentioned time and again in premodern writings (Milner, 2019). The prominence of this principle, it can be argued, helps to explain why Communism, per se, has not been a problem in Malaysia's foreign relationships. Certainly, there was unhappiness about Communist China's support of the Malayan Communist Party - that entailed interference in Malaysian internal affairs. But Malaysia did not hesitate to develop relations with Vietnam, Cambodia and Laos at the end of the IndoChina War and was keen to incorporate these countries in ASEAN - despite their Communist political systems. Also, the fact that China is Communist has not in itself been a deterrent to developing relations with that country.

The other hardcore perspective concerns what could best be called 'moral balance' - which is, as the phrase suggests, a moral not a power preference. You see this sentiment referred to time and again in pre-modern writings, including in the advice given by a dying ruler to his son. Always the point is made, you must seek advice in every direction, be open to all perspectives. The term 'adil' is often used to describe a good ruler, and it seems to me - if you look at the exact way in which 'adil' is used - that it is intended not so much to mean 'just' (the translation often given) but rather 'fair', or even 'morally balanced'. The linguist, Asmah Haji Omar, provides a further insight into Malay political thought. She has explained that the closest term to 'diplomacy' in Malay is 'timbang rasa' - or 'weigh feelings of.' This, says Asmah, is the opposite of 'taking sides' (Milner, 2015: 32 - 40).

In modern times, I suggest, the preference for moral balance could help explain the Malaysian long-term advocacy of equi-distance in relations with major powers and why Malaysia today seems comfortable with a range of major powers in the region, and uncomfortable about alliance-forming and major-state confrontation. Again, I cannot elaborate here but moral balance as a preference is also quite consistent with Malay aesthetic emphasis on harmony and balance in various areas of art and craft. 
Moral balance, of course, is not usually a key term in International Relations analysis, and - as I have said - operates outside the power register. But it is one of those cultural specificities which we have to confront in trying to comprehend what is happening in Malaysia-China relations. Alongside the injunction against non-interference, the lack of emphasis on sovereign territorial borders, and the preference for embracing rather than power-balancing when facing a potentially threatening major power and also the possession of a heritage of mousedeer diplomacy in which hierarchy offers opportunities as well as dangers - moral balance contributes to a strategic and diplomatic culture capable of influencing Malaysian realworld decisions. My impression is that the ideational heritage of all the key ASEAN states is worth investigating in this matter. It is a more difficult task than citing 'identity politics' as the catch-all driver - but it is more rewarding (Raymond, 2018).

\section{CONCLUSION}

Globalisation has certainly been stopped in its tracks, at least as a venture leading to a universal liberal consensus. Fukuyama is right to take note of all types of interest groups and social unities emerging today but it is not enough to summon up 'identity politics' as the 'master concept' that 'unifies' all that is going on. Surges of Islamisation, like the emergence of a Chinese civilisation state (which looks backward as well as forward) or the distinctive way in which Malaysia has approached China - these developments are not merely about recognition. They reveal modes of understanding and political ideals which tend to be unfamiliar to many Westerners, including most modern Western analysts. Such cultural specificities raise the issue of whether the key concepts often employed in writing about international dynamics in the Asian region are adequate. It is here that current interest in non-Western IR offers a potential that reaches beyond Fukuyama's work.

The current limitations of International Relations as a discipline have been pointed to by the senior Singapore diplomat, Bilahari Kausikan. Although he studied IR at university he found that in his 30 years as a diplomat the "study of history, literature and philosophy" offered a "better 
preparation for understanding international affairs." IR, he considered, was "generally too mechanical, gives insufficient weight to human agency, and is often based on premises that are irrelevant to Singapore's specific circumstances" (Kausikan, 2016). This observation may be a little harsh particularly in the light of recent work in IR - but, at the very least, Bilahari's comment should reinforce what I have written above in providing grounds for promoting inter-disciplinary partnerships.

With globalisation at the crossroads - with the internet and social media often promoting real plurality not homogeneity - the need to understand different cultural specificities becomes increasingly serious. The range of cultural perspectives which we now face cannot be summed up merely as 'identity politics'. The analytical frameworks which have been dominant in modern times themselves need review. There is a need to be open to new 'logics' - as Wang Gungwu and Charles Taylor in their different ways have suggested.

Today we are understandably engaged not merely in a reflective deliberation at the end of an historical era, but also in the construction of new paradigms - frameworks that will help us make sense of a postglobalisation, post-liberal, probably post-Western era. The 'return of culture' might, for the moment, be as good a framework as any for capturing the range of issues we currently have to tackle. Fukuyama's 'identity politics', as I have suggested is too narrow and entangled in the paradigm which it seeks to replace.

\section{REFERENCES}

(Huntington, Samuel, P. 1993) or (Huntington, Samuel, P. 1996). The clash of civilizations? Foreign affairs. New York: Simon \& Schuster.

'Bersatu banteras ancaman liberalisme'. Unite to wipe out the threat of liberalism. (2016). Utusan Malaysia. Retrieved from http://www.utusan.com.my/ rencana/agama/bersatu-banteras-ancaman-liberalisme-1.390940

Catherine Wong. (2018). Return of Mahathir Mohamad to ASEAN may put a third power in the picture - Japan. South China Morning Post. Retrieved from https://www.scmp.com/news/china/diplomacy-defence/article/2157697/ return-mahathir-mohamad-asean-may-put-third-power 
Chua, B. H. (2017). Liberalism disavowed: Communitarianism and state capitalism in Singapore. Singapore: NUS Press.

Evans, G. (1993). The challenges for Australian Foreign Policy. Lecture to the Queensland Branch of the Australian Institute of International Affairs. Brisbane. Retrieved from http://www.gevans.org/speeches/ old/1993/150593_fm thechallengeofasia.pdf

Fukuyama, F. (2018). Identity: Contemporary identity politics and the struggle for recognition. London: Profile Books Ltd.

Geertz, C. (1973). The interpretation of cultures. New York: Basic Books.

Geertz, C. (1995). After the fact: Two countries, four decades, one anthropologist. Cambridge: Harvard University Press.

Global Times. (2018, 20 August). Mahathir visit firms up China-Malaysia ties. Retrieved from http://www.globaltimes.cn/content/1116274.shtml

Ikenberry, G. J. (2011). Liberal Leviathan: The origins, crisis, and transformation of the American world order. Princeton: Princeton University Press.

Jaipragas, B. (2018). We like rich partners: Malaysia's Mahathir heads to China for fence-mending trip. South China Morning Post. Retrieved from https:// www.scmp.com/week-asia/politics/article/2160022/malaysias-mahathirtake-genial-approach-china-visit

Kaplan, R. (2014). Asia's cauldron: The South China Sea and the end of a stable Pacific. New York: Random House.

Kausikan, B. (2016). Dealing with an ambiguous world. Singapore: World Scientific.

Kuik, C.-C. (2013). Making sense of Malaysia's China Policy: Asymmetry, proximity and elite's domestic authority. The Chinese Journal of International Politics, 6 (4), 429-467. https://doi.org/10.1093/cjip/pot006

Lo, K. (2019). Malaysia's Mahathir backs belt and road but insists on open trade routes. South China Morning Post. Retrieved from https:/www.scmp.com/ news/china/diplomacy/article/3007874/malaysias-mahathir-backs-chinasbelt-and-road-insists-open

Lokman Mansor. (2018). Malaysia to remain friendly with China: Dr M. New Straits Times. Retrieved from https://www.nst.com.my/news/ nation/2018/06/378757/malaysia-remain-friendly-china-dr-m.

Milner, A. (2000). What happened to 'Asian Values? In Gerald Segal \& David S.G. Goodman (Ed.). Towards Recovery in Pacific Asia (pp. 56-68). London: Routledge.

Milner, A. (2011). The Malays. Oxford: John Wiley and Sons Ltd.

Milner, A. (2015). Nama, group-binding and moral balance: Themes and origins of Malaysian foreign policy. Kuala Lumpur: ISIS Malaysia.

Milner, A. (2015). Will ASEAN continue to be the cornerstone of Malaysian Foreign Policy: The community-building priority. Kuala Lumpur: ISIS Malaysia.

Milner, A. (2016). Australia should listen to SE Asian views on dealing with China. Retrieved from https://www.researchgate.net/publication/330983220_ Australia_should_listen_to_SE_Asian_views_on_dealing_with_China 
Milner, A. (2017). Culture and the international relations of Asia. Journal Pacific Review, 30 (6), 857-869. https://doi: 10.1080/09512748.2017.1315165

Milner, A. (2017). Sovereignty and normative integration in the South China Sea: Some Malaysian and Malay perspectives. In Lowell Dittmer \& Ngeow Chow Bing (Eds..). Southeast Asia and China: A Contest in Mutual Socialization (pp. 229-246). Singapore: World Scientific. https://doi. org/10.1142/9789813146884_0011

Milner, A. (2019). Long-term themes in Malaysian Foreign Policy: Hierarchy diplomacy, non-interference and moral balance. Asian Studies Review, 44 (2), 1-19.

Milner, A. \& Siti Munirah Kasim. (2018). Beyond sovereignty: Non-Western international relations in Malaysia's foreign relations. Contemporary Southeast Asia, 40 (3), 385.

Ono, Y. (2018). Malaysia should "make best use" of Belt and Road, Mahathir says. Nikkei Asian Review. Retrieved from https://asia.nikkei.com/Spotlight/ The-Future-of-Asia-2018/Malaysia-should-make-best-use-of-Belt-andRoad-Mahathir-says

Peel, M. (2016). Duterte calls for calm as SE Asia grapples with sea ruling. Financial Times. Retrieved from https://www.ft.com/content/3d42fb66-49b5-11e6$8 \mathrm{~d} 68-72 \mathrm{e} 9211 \mathrm{e} 86 \mathrm{ab}$

Pinar, B. (2007). Thinking Past 'Western' IR? Journal Third World Quarterly, 29 (1), 11.

Raymond, G. V. (2018). Thai military power: A culture of strategic accommodation. Contemporary South East Asia, 40 (2), 342-345. Copenhagen: NIAS Press. doi:10.1355/cs40-21. Retrieved from https://www.youtube.com/ watch? $\mathrm{v}=$ VVgialg6Or4

Shahrbanaou, T. (2010). International relations theory and the Islamic worldview. In Amitav Acharya \& Barry Buzan (Eds.). Non-Western International Relations theory (pp. 188). London: Routledge.

Shen, D. (2014). Reconciliation in the South China Sea. In CSCAP Regional Security Outlook (pp. 35-36). Canberra, Australia: Council for Security Cooperation in the Asia Pacific (CSCAP).

Sultan Nazrin Shah's Keynote Address at the ASEAN-Australia Dialogue. (2018). Retrieved from https://aei.um.edu.my/keynote-address-by-hisroyal-highness-sultan-nazrin-muizzuddin-shah-at-the-asean-australiadialogue-2018

Taylor, C. (1992). Multiculturalism and the politics of recognition. Princeton: Princeton University Press.

Thayer, C. (2016). After the ruling: Law fare in the South China Sea. The Diplomat. Retrieved from https://thediplomat.com/2016/08/after-the-ruling-lawfarein-the-south-china-sea/

Waltz, K. N. (1996). International politics is not a foreign policy. Journal Security Studies, 6 (1), 54. 
Wang, G. (1996/1997). A Machiavelli for our times. Center for the National Interest, 46, 69-73.

Yan, X. (2013). Ancient Chinese thought, modern Chinese power. Princeton: Princeton University Press.

YouTube. (2018). Mahathir clarifies his position on China. South China Morning Post. Retrieved from https://www.youtube.com/watch?v=VVgialg6Or4

Zhang, Y. \& B., Barry. (2012). The Tributary system as international society in theory and practice. The Chinese Journal of International Politics, 5 (1), 3-36.

Zuraidah Ibrahim \& Jaipragas, B. (2018). Mahathir Mohamad Q\&A: Malaysian PM on Beijing, Jack Ma and why battleships in the South China Sea are a bad idea. South China Morning Post. Retrieved from https://www.scmp. com/week-asia/politics/article/2151394/mahathir-mohamad-qa-malaysianpm-beijing-jack-ma-and-why 
